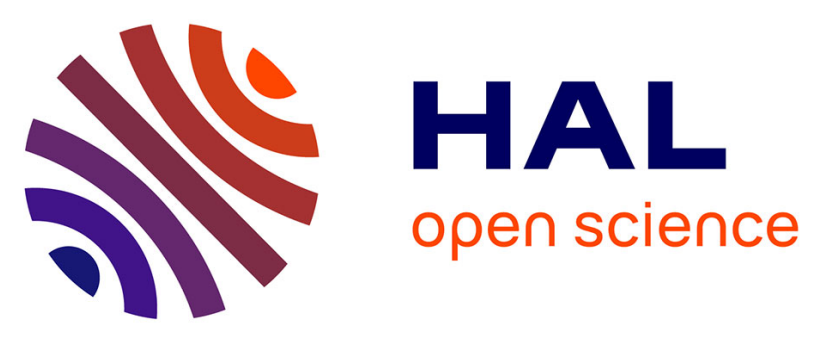

\title{
Mechanical pretreatment of municipal biowaste to produce an aqueous slurry dedicated to anaerobic digestion
}

Paul Moretti, Mariana Moreira de Oliveira, Rémy Bayard, Pierre Buffiere, Joacio Morais de Araujo, Armando Borges de Castilhos, Rémy Gourdon

\section{To cite this version:}

Paul Moretti, Mariana Moreira de Oliveira, Rémy Bayard, Pierre Buffiere, Joacio Morais de Araujo, et al.. Mechanical pretreatment of municipal biowaste to produce an aqueous slurry dedicated to anaerobic digestion. Environmental Science and Pollution Research, 2021, 28 (16), pp.20586-20597. 10.1007/s11356-020-11836-3 . hal-03234581

\section{HAL Id: hal-03234581 \\ https://hal.science/hal-03234581}

Submitted on 26 May 2021

HAL is a multi-disciplinary open access archive for the deposit and dissemination of scientific research documents, whether they are published or not. The documents may come from teaching and research institutions in France or abroad, or from public or private research centers.
L'archive ouverte pluridisciplinaire HAL, est destinée au dépôt et à la diffusion de documents scientifiques de niveau recherche, publiés ou non, émanant des établissements d'enseignement et de recherche français ou étrangers, des laboratoires publics ou privés. 


\section{Mechanical pretreatment of municipal biowaste to produce an aqueous}

\section{2 slurry dedicated to anaerobic digestion}

3

4 Paul Moretti ${ }^{1}$, Mariana Moreira de Oliveira ${ }^{2}$, Rémy Bayard ${ }^{1 *}$, Pierre Buffiere ${ }^{1}$, Joacio

5 Morais de Araujo $^{2}$, Armando Borges de Castilhos Jr. ${ }^{3}$, Rémy Gourdon ${ }^{1}$

6 *Corresponding Author: Rémy Bayard

7 DEEP - INSA Lyon - Université de Lyon

8 20, Avenue A. Einstein, 69621 Villeurbanne Cedex, France

$9 \quad$ Tel. +33 4-72-43-87-53

10 E-mail: remy.bayard@insa-lyon

11 11 Université de Lyon, INSA Lyon, DEEP Laboratory, EA7429, F-69621 Villeurbanne

12 cedex, France

13 2Dep. Engenharia Civil e Ambiental DECA - UFPB. João Pessoa - Brasil

$14{ }^{3}$ Universidade Federal de Santa Catarina, Department of Sanitary and Environmental

15 Engineering, Florianópolis. CEP 88040-970, Santa Catarina State, Brasil.

16

17 Abstract

18 This study investigated a wet mechanical pretreatment to improve methane production by

19 anaerobic digestion from biowaste material by separating a biodegradable aqueous slurry

20 fraction (ASF) from a more recalcitrant particulate fraction (PF). Four source-sorted

21 municipal biowaste were studied, namely Household (HBW), Supermarket (SBW),

22 Restaurant (RBW) and Green Biowaste (GBW). The treatment consisted in soaking the

23 waste in water and then press the slurry through a grid with 3-mm openings to separate

24 the 2 fractions. Methane production of ASF and PF obtained from the 4 biowastes were 
measured using the BMP protocol and compared to the potential of the respective untreated biowaste.

27 Results were very different for GBW as compared to the other $3 \mathrm{BW}$. With GBW, which 28 was the most lignocellulosic of the BW studied, only $17 \%$ of the initial methane potential 29 was recovered in the ASF. The extraction was much better on the other biowastes and 30 increased in the following order: $\mathrm{HBW}(58 \%) \simeq \mathrm{RBW}(57 \%)<\mathrm{SBW}(67 \%)$. The ASF

31 from these biowastes exhibited low total solids contents and high BMPs (416, 408 and $32423 \mathrm{NL}_{\mathrm{CH} 4} \cdot \mathrm{g}^{-1}$ vs for HBW, RBW and SBW respectively).

33 The experimental results obtained in this study therefore showed that wet pressing 34 separation was an efficient pretreatment to improve and facilitate methane production by 35 anaerobic digestion of biowaste such as HBW, RBW and SBW.

37 Keywords: biomethane potential; municipal organic waste; wet press separation; energy recovery; biodegradable organic fraction; bioconversion

\section{Graphical abstract}

40 Mechanical pretreatment of municipal biowaste to produce an aqueous

41 slurry dedicated to anaerobic digestion

42 P. Moretti ${ }^{1}$, M. Moreira de Oliveira ${ }^{2}$, R. Bayard ${ }^{1 *}$, P. Buffiere ${ }^{1}$, J. Morais de Araujo ${ }^{2}$, A. Borges de Castilhos Jr ${ }^{3}$, R. 43 Gourdon $^{1}$ 

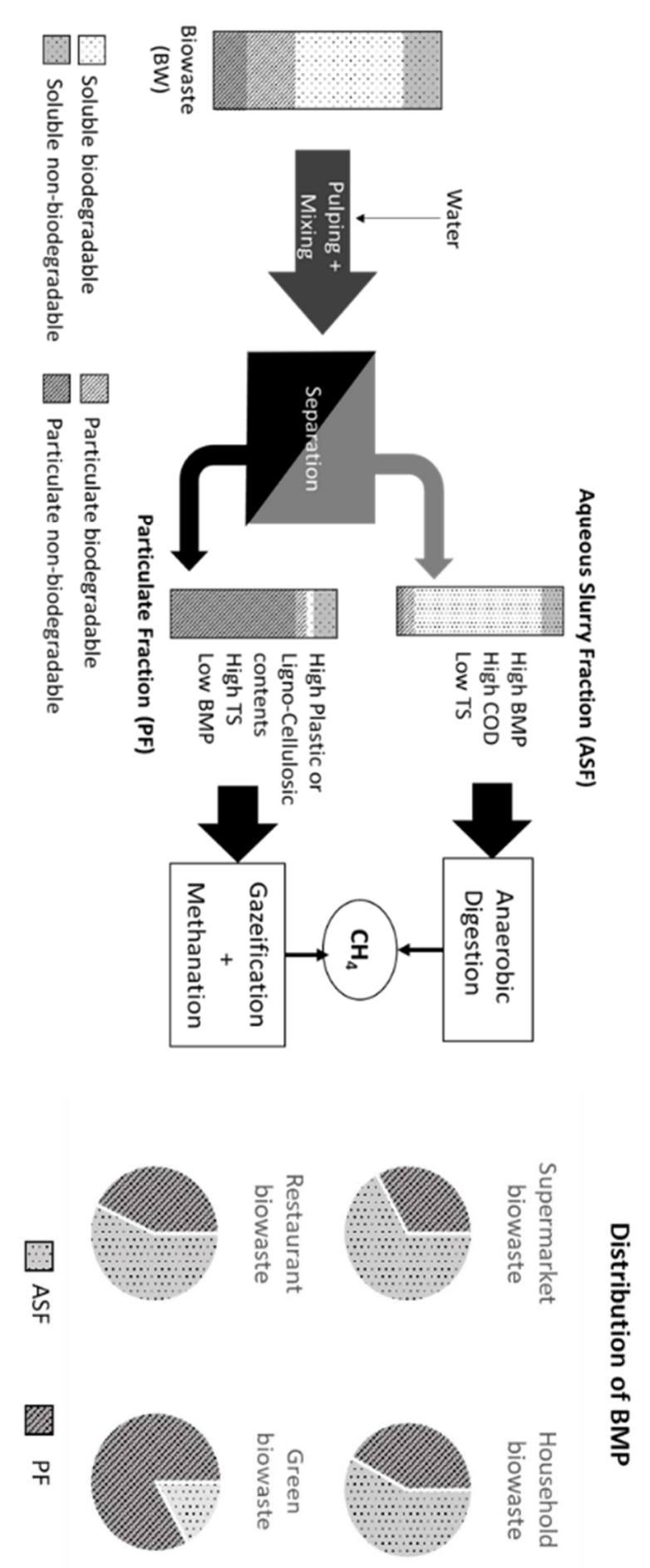


\section{Introduction}

47 Municipal solid waste production (MSW) is still growing in most European cities despite 48 the efforts made to reduce it (Fisgativa et al. 2016; Braguglia et al. 2018). MSW 49 comprises several categories of waste collected on urban territories, including biowaste 50 (BW). According to the European Directive 2018/851, BW includes biodegradable 51 garden and park waste, food waste from restaurants and supermarkets, and the 52 biodegradable organic fraction of household waste (European Union 2008). The 53 production of municipal biowaste in EU-28 was estimated to $86.10^{6}$ Tons per year.

54 Household BW and Garden BW represented $60 \%$ and $35 \%$ of this production respectively 55 (European Environment Agency 2020). Due to their biological origins and specific 56 characteristics, BW are potential resources of organic matter for the production of compost, nutrients, or energy (Escamilla-Alvarado et al. 2017).

Selective collection of BW is developing fast in several European urban areas (Bernstad et al. 2014; Sidaine and Gass 2013). European regulations will make it compulsory in

612023 (European Union 2018). This evolution should improve the quality of the recovered organic matter and thereby favor its reuse for agricultural purposes in the future (Hansen et al. 2007). However, the possible presence of undesirable materials such as glass,

64 plastics, ceramics, etc and even hazardous substances such as heavy metals and other 65 micropollutants, is likely to remain a significant risk in big cities where the quality of the 66 selective collection may be degraded for various reasons (Weithmann et al. 2018). In this

67 context, energy recovery appears more adapted in urban territories because it would be less sensitive to possible contaminations of the resource.

69 
70 Among the different possible strategies to convert BW into energy, methane production is attractive in urban territories. Methane has a high energy content of $10 \mathrm{kWh}$ per $\mathrm{Nm}^{3}$, several possible energy usages, and it is already distributed in many cities through existing grids. BW however contains different proportions of biodegradable matter and more recalcitrant constituents such as lignocellulosic compounds (St Joly et al. 2000; Fisgativa et al. 2017). Several types of processes have therefore been used to optimize methane production from BW. Biological anaerobic digestion is best adapted to convert the humid and readily biodegradable organic constituents (Capson-Tojo et al. 2016). Thermochemical processes such as gasification would be more adapted for their less humid and more recalcitrant constituents (Vakalis et al. 2017). Pretreatments of BW are

80 therefore needed to separate the 2 types of constituents and apply adapted treatments to each of them (Rodriguez-Valderrama et al. 2020).

82

Mechanical treatments have been used for decades in solid waste treatment applications, and still are. Sorting operations are used to remove undesirable materials or, on the contrary, recover valuable constituents from a waste flow (Ariunbaatar et al. 2014; Pognani et al. 2012). Several authors have used mechanical operations as pretreatments

87 prior to anaerobic digestion (Hansen et al. 2007; Do Carmo Precci Lopes et al. 2019). Press-separation was investigated to remove undesirable impurities and recalcitrant particulate matter from BW (Jank et al. 2015) or to produce a biodegradable aqueous

90 slurry (Micolucci et al. 2015a; Do Carmo Precci Lopes et al. 2019). However, most of 91 published studies on the subject have concerned household BW mixed or not with green waste. Do Carmo Precci Lopes et al. (2019) reported that the design and implementation

93 of mechanical pretreatments was still a challenging step to convert BW into methane 
94 and/or compost. To our knowledge, no comparative study has been conducted on specific

95 BW categories as reported in the present article.

96

97 The present study investigated the implementation of wet pressing as a mechanical 98 pretreatment of 4 types of BW to optimize their anaerobic digestion. The treatment was 99 meant to generate an aqueous slurry fraction (ASF) expected to extract as much as 100 possible the soluble readily biodegradable constituents, and a particulate fraction (PF)

101 expected to collect fibrous and particulate constituents along with undesirable materials

102 that may be present. The aqueous slurry is to be oriented to anaerobic digestion to produce

103 methane, whereas the particulate fraction would be treated by gasification followed by

104 methanation of syngas.

\section{Materials and methods}

$106 \quad 2.1 \quad$ Selection and characterization of biowaste samples

107 The categories of BW material investigated in this study were selected in collaboration

108 with the technical services of Lyon Metropolitan Area, France, considering the following 109 criteria:

110 - Quantitative production on the considered territory;

111 - Availability (dispersion, accessibility), collection costs and possible difficulties;

112 - Territorial specificities, public policies, political strategies, other operational issues.

113 Four types of BW were selected, namely Garden BW (GBW) collected from domestic,

114 municipal and private sources; BW from restaurants (RBW) collected from private and

115 public collective catering sources including schools; Household kitchen BW (HBW)

116 collected from a set 200 hundred people (faculty members, staff and students of our 
117 institution) who separated at source their own food waste; BW from supermarkets (SBW)

118 collected from a company specialized in depackaging of mixed supermarket food waste.

119 Representative samples of about $200 \mathrm{~kg}$ of each BW were collected in September 2018

120 following standard sampling guidelines and protocols NF EN 14899 (2006). Each sample

121 was homogenized by coarse shredding using a Blik BB350, and analyzed as reported in

122 a previous work (Moretti et al. 2020). All analyses were duplicated and results were well

123 reproducible. Table S1 (supplementary data) gathers the physico-chemical composition

124 and biodegradation potential of each BW, which were determined as described in Moretti

125 et al. (2020).

126 
128 The protocol followed to treat the different BW samples is illustrated in Figure 1. Assays 129 were done in triplicates. Each shredded sample was soaked in de-ionized water in a $1 \mathrm{~L}$ 130 glass beaker. Two liquid to solid ratios were tested: 5 and $10 \mathrm{~g}$ of water per $\mathrm{g}$ of dry BW. $131250 \mathrm{~mL}$ of the suspensions were mixed for 20 minutes at a room temperature of $23+/ 1{ }^{\circ} \mathrm{C}$,

132 in a Heidolph REAX 20 tumbler agitator set at $10 \mathrm{rpm}$. The objective of this operation 133 was to extract as much as possible the soluble and colloidal organic matter from the BW 134 samples.

135 Lab-scale filtration-compression cells were then used to separate ASF from PF. The 136 experimental setup is shown in Figure S1 (supplementary data). It was made of three 137 0.46L cylindrical stainless steel cells of $70 \mathrm{~mm}$ inner diameter and $120 \mathrm{~mm}$ height. A 138 stainless-steel disk perforated with holes of $3 \mathrm{~mm}$ diameter was placed at the bottom of 139 the cylinder. The BW suspensions obtained after soaking in water were introduced into 140 the 3 cells in order to run triplicate assays for each BW sample. The filtrate (ASF) was 141 collected from the bottom of the cells and its mass monitored online over time. After 20 142 minutes pressing, the system was stopped and PF was collected from the cells.

144 The experimental conditions tested are gathered in Table 1. Due to the high and regular 145 annual production of HBW and the current evolution of the European regulations which 146 will make it compulsory to collect this waste selectively and manage it specifically in 1472023 , HBW was selected as the resource to focus on in priority. The first two series of 148 experiments (first 2 lines of Table 1) were carried out only with the HBW. These 149 experiments compared 2 pressures ( 3 and 6 bars) and L/S ratios for the wet-pressing 150 treatment. The treatment duration was fixed at $20 \mathrm{~min}$. Preliminary studies had shown 151 that this duration would guarantee no kinetic limitations that could bias the comparisons 
152 between the waste samples. The last series of experiments was done to compare the results

153 obtained with the different waste samples. These experiments were carried out at a given

154 pressure (6 bars) and given L/S ratio (10). The fours BW were studied for comparison.

155

156 2.3- Analysis of aqueous slurry (ASF) and particulate fractions (PF)

157

158

\subsubsection{Physical and chemical analyses}

159

160 ASF and PF obtained from the pretreatment of each BW were characterized in triplicates.

161 Total solids (TS) were measured by drying for $24 \mathrm{~h}$ at $105^{\circ} \mathrm{C}$ known masses of samples 162 and weigh them dry (Baird and Bridgewater 2017). Volatile Solids (VS) were determined 163 as the mass loss upon calcination at $550{ }^{\circ} \mathrm{C}$ for $4 \mathrm{~h}$ (Baird and Bridgewater 2017).

164 Chemical oxygen demand (COD), Total Kjeldahl nitrogen (TKN), and ammonia nitrogen $165\left(\mathrm{NH}_{3}-\mathrm{N}\right)$, were analyzed according to standard methods (Baird and Bridgewater 2017) on samples dried at $70{ }^{\circ} \mathrm{C}$ for 3 days (until to constant weight) and crushed down to below 2 mm. Water soluble carbohydrates (WSC) and Volatile fatty acids (VFA) were analyzed

168 only in the aqueous slurries by Ionic Chromatography Dionex ICS5000 Thermo Fisher 169 after filtration at $0.45 \mu \mathrm{m}$.

\subsubsection{Biochemical methane potential (BMP)}

173 Biochemical methane potentials (BMP) were measured on each selected BW and on ASF and PF, following the guidelines reported by Holliger et al. (2016). For BW samples and $\mathrm{PF}, \mathrm{BMP}$ assays were conducted at $35^{\circ} \mathrm{C}$ in $2 \mathrm{~L}$ glass vessels, for $\mathrm{ASF}$, assays was

176 performed in $0.5 \mathrm{~L}$. The inoculum was a fresh digested sludge taken from the wastewater 
177 treatment plant of La Feyssine, Lyon, France (TS 2.0-3.3\%wt; VS 1.4-2.2\%wt). The

178 inoculum to substrate VS ratio was $2 \mathrm{~g} / \mathrm{g}$. Once filled, the glass vessels were purged with

$179 \mathrm{~N}_{2} / \mathrm{CO}_{2}(80 / 20 \% \mathrm{v} / \mathrm{v})$ gas for about 2 minutes, sealed and equilibrated at $35^{\circ} \mathrm{C}$. Blanks

180 containing only the inoculum and water were systematically monitored along with each

181 series of assays in order to correct the recorded BMP from residual methane production

182 of the inoculum. Positive controls with cellulose were also monitored.

183 All blanks and assays were triplicated. Biogas production was followed by monitoring

184 the pressure in the flasks using a Digitron precision manometer. Biogas was released from

185 the flasks when the pressure exceeded $1200 \mathrm{hPa}$. Gas composition was analyzed using an

186 Agilent 3000 micro gas chromatography equipped with a thermal conductivity detector

187 (GC-TCD). Molsieve 5A (14 m length; pore size: $5 \AA$ A ) and PoraPlot A (10 m length;

$1880.320 \mathrm{~mm}$ ID) columns were used as stationary phases for GC-TCD, using Argon as a

189 carrier gas. According to the protocol described by Holliger et al. (2016), tests were

190 stopped when the daily biogas production was less than $1 \%$ of the total volume of biogas

191 produced.

192 The rate of methane production was determined from the net methane production (i.e.,

193 after subtracting the blank methane production) according to a first order kinetic model

194 (equation 1).

$$
V_{C H_{4}}(t)=V_{\max }\left(1-e^{-k t}\right)
$$

where $V_{\mathrm{CH}_{4}}(\mathrm{NL})$ is the cumulated volume of methane produced at time $\mathrm{t} ; t(\mathrm{~d})$ is the time,

$196 V_{\max }(\mathrm{NL})$ the maximum volume of methane produced, and the first order kinetic

197 constant. 

aqueous slurry and particulate fraction

201

202 Mass balance calculations were performed on total solids (TS), volatile solids (VS), COD 203 and BMP using the results obtained from the analyses done on each BW before treatment 204 and on the fractions ASF and PF obtained after separation.

205 Parameters $x_{i, A S F}$ and $x_{i, P F}$ were defined as the proportions of parameter $i$ (TS, VS, COD 206 and methane production) of each respective BW sample which were transferred into ASF 207 and PF fractions during the pretreatment operations. They were expressed in $\% \mathrm{w} / \mathrm{w}$ and 208 calculated according to equations (2), (2'), (3), (3'), (4) and (4').

209

$$
\begin{aligned}
& x_{V S, A S F}=\frac{m_{V S, A S F}}{m_{V S, A S F}+m_{V S, P F}} \cdot 100 \\
& x_{C H 4, A S F}=\frac{V_{C H 4, A S F}}{V_{C H 4, A S F}+V_{C H 4, P F}} \cdot 100 \\
& x_{C O D, A S F}=\frac{m_{c o d, A S F}}{m_{c o s, A S F}+C O D_{c o d, P F}} \cdot 100 \\
& x_{V S, P F}=\frac{m_{V S, P F}}{m_{V S, A S F}+m_{V S, P F}} \cdot 100 \\
& x_{C H 4, P F}=\frac{V_{C H 4, P F}}{V_{C H 4, A S F}+V_{C H 4, P F}} \cdot 100
\end{aligned}
$$

210 Where:

$211 \mathrm{~m}_{\mathrm{s}, \mathrm{ASF}}: \quad$ Mass of total or volatile solids in ASF ( $\mathrm{g}_{\mathrm{TS}}$ or $\mathrm{g}_{\mathrm{VS}}$ )

$212 \mathrm{~m}_{\mathrm{s}, \mathrm{PF}}$ : $\quad$ Mass of total or volatile solids in PF ( $\mathrm{g}_{\mathrm{TS}}$ or $\left.\mathrm{g}_{\mathrm{VS}}\right)$

$213 \mathrm{~V}_{\mathrm{CH} 4, \mathrm{ASF}}$ : Biomethane production measured on ASF $\left(\mathrm{NL}\right.$ of $\left.\mathrm{CH}_{4}\right)$

$214 \mathrm{~V}_{\mathrm{CH} 4, \mathrm{PF}}$ : $\quad$ Biomethane production measured on $\mathrm{PF}\left(\mathrm{NL}\right.$ of $\left.\mathrm{CH}_{4}\right)$

$215 \mathrm{~m}_{\mathrm{cod}, \mathrm{ASF}}: \quad$ Mass of COD measured in ASF $\left(\mathrm{g}_{\mathrm{O} 2}\right)$

$216 \mathrm{~m}_{\mathrm{cod}, \mathrm{PF}}$ : $\quad$ Mass of COD measured in PF $\left(\mathrm{g}_{\mathrm{O} 2}\right)$ 


\section{Results and discussion}

$220 \quad 3.1 \quad$ Effects of pressure and L/S ratio on household biowaste (HBW) pretreatment

221 The effects of the operational conditions were investigated using this BW sample.

222 From preliminary experiments (not shown), three sets of conditions were compared: (i)

22320 minutes soaking at a liquid to solid (L/S) ratio of $5 \mathrm{~g}$ of water per $\mathrm{g}$ of HBW dry solids

224 followed by pressing under 3 bars or (ii) 6 bars, (iii) 20 minutes soaking at a L/S ratio of

22510 followed by pressing under 6 bars (Table 1 ).

227 Figure 2 shows the dynamics of extraction of ASF recorded during the pressing operation 228 of soaked HBW under the different operational conditions. Time 0 on the graphs showed 229 the time when pressure was applied. However, small volumes of solutions dripped out of 230 the cell by gravity before, and were included in the monitoring. The curves revealed 3 231 successive phases which resulted from the two processes involved in the operation. In a 232 first phase of 10 to 20 seconds corresponding to the filtration phase, the extracted mass increased very sharply and linearly. According to the conventional theory of Ruth et al.

234 (1933a), which was verified by Vesilind (1994) on sludge material, filtration involves the mobilization of free water under the effect of pressure and the convective transfer of the 236 suspended solids smaller than the size of the perforations in the filter.

237 A filtration cake consisting of the PF of HBW was thereby rapidly formed at the surface 238 of the filter disk by accumulation of the suspended solids larger than the disk openings 239 (see figure S2). This phenomenon rapidly reduced the permeability at the surface of the 240 disk and therefore the rate of ASF extraction slowed down over the next 1-2 minutes. 241 This was the second phase, corresponding to the formation and consolidation of the filter 
242 cake. Particles in the filter cake were compressed, increasing furthermore the resistance

243 to mass flow. Finally, the last phase of the curves observed in the following 18-19 minutes

244 corresponded to the dewatering of the filtration cake. The extraction rate slowed down

245 progressively until no significant extraction was recorded, indicating that all free water

246 had then been removed from PF. At the completion of the assays ( $20 \mathrm{~min}), 69 \%$ of the

247 initial mass of soaked HBW was extracted at 6 bars and only $49 \%$ at 3 bars for the ratio 248 of 5 g water. $\mathrm{g}^{-1}$ Ts.

249 Increasing the pressure from 3 to 6 bars at a L/S ratio of $5 \mathrm{~g}_{\text {water. }} \mathrm{g}^{-1}$ Ts increased the mass 250 extracted in the filtration phase from about $20 \%$ to about $35 \%$. of the initial mass (Fig.

251 2). However, the curves over the last phase (dewatering of filter cake) were very similar

252 at 3 and 6 bars. Increasing the pressure also increased logically the TS content of PF from 25326 to $41 \%$ of the mass of the fraction (Table 2) since more aqueous solution was 254 extracted. TS content of ASF also increased slightly from 7.1 to $9.3 \%$ probably due to 255 the extraction of dissolved and colloidal compounds.

256 Increasing the L/S ratio from 5 to $10 \mathrm{~g}_{\text {water. }} \mathrm{g}^{-1} \mathrm{TS}$ in the soaking operation of HBW 257 increased furthermore the extraction during the filtration phase under 6 bars from $69 \%$ at $258 \mathrm{~L} / \mathrm{S}$ of 5 to $88 \%$ of the initial mass at L/S of 10 . This result was explained by the higher 259 proportion of water in the initial soaked HBW, which was easily extracted in the filtration 260 phase. TS content in ASF was logically smaller at L/S of 10 as compared to L/S of 5 261 (Table 2). It can be noted that TS contents obtained here in the aqueous fraction (from 5 262 to $9.3 \%$, Table 2) were lower than reported in similar studies done on urban biowaste by 263 other authors where TS contents as high as 18 to $31 \%$ were reported (Jank et al. 2015; do

264 Carmo Precci Lopes et al. 2019; Micolucci et al. 2015b). This parameter however is 265 strongly modified by the experimental conditions, which vary from one study to another. 
266 For example, do Carmo Precci Lopes et al. (2019) studied dry press separation with 12

267 mm openings, whereas Jank et al. (2015) used filters with $8 \mathrm{~mm}$ openings.

268

269 The mass proportions of each fraction produced from HBW were calculated by equations

2701 and 1' (TS) and 2 and 2' (VS). Results are shown in Fig. 3.

271 Fig. 3a showed that the major part of the initial soaked waste mass was collected in ASF.

272 This was logical since this fraction received all the free water present in the initial soaked

273 waste. Increasing the pressure during the pressing operation allowed to extract more free

274 water and thereby increased the mass proportion of ASF. Increasing the liquid to solid

275 ratio in the soaking phase had the same effect for the same reason. Using a similar

276 approach as in this study, Jank et al. (2015) reported almost 85\%ww extraction in the

277 aqueous fraction with a filtration disk perforated with $8 \mathrm{~mm}$ holes. Similar results were

278 reported by Novarino and Zanetti (2012) with extruded HBW at $8 \mathrm{~mm}$ holes. Hansen et

279 al. (2007) reported lower values with 55\% to 64\%ww extraction using an not-optimized

280 industrial screw press process.

281 Figs. $3 \mathrm{~b}$ and $\mathrm{c}$ however showed that the dry matter (total solids, TS) initially present in

282 the soaked BW was collected mostly in PF. The organic matter (VS) followed the same

283 pattern as the total solids. Increasing the pressure from 3 to 6 bars in the pressing operation

284 or the L/S ratio in the soaking phase was found to increase the proportion of the VS

285 extracted into PF. This result was probably due to a stronger extraction of particulate

286 organic matter from the soaked waste into ASF by the increased amounts of free water

287 extracted into ASF under these conditions.

2893.2 Pretreatment of the four biowaste by soaking at $10 \mathrm{~g}_{\mathrm{w}} \cdot \mathrm{gTs}^{-1}$ followed by pressing at 6

$290 \quad$ bars) 
3.2.1 Total mass, total solids and volatile solids distribution between aqueous slurry and particulate fraction

295 Figure 4 shows the dynamics of the extraction of ASF recorded in the operation of 296 pressing of the four soaked BW investigated.

The curves obtained with all waste samples exhibited a very sharp slope at the very 299 beginning of the treatment, corresponding to the first phase, or filtration phase, discussed 300 above, and a flat slope in the last phase corresponding to the filter cake dewatering 301 process. The second phase showed however two distinct patterns. With GBW and SBW samples, phase 2 was almost not observed, whereas it occurred over 1 to 2 minutes with RBW and HBW samples. This result was attributed at different characteristics in the

304 formation and consolidation of the filter cake. GBW probably generated a more porous and less compressible filter cake than RBW, SBW and HBW, due to is higher contents in

306 lignocellulosic organic compounds. It was therefore probably more rapidly stable, 307 resulting in a very short phase 2 . At the end of the treatment, $76 \%$ (GBW) to $90 \%$ (SBW) 308 of the initial mass of soaked waste was collected in ASF.

310 Figure $5 \mathrm{a}, \mathrm{b}$ and $\mathrm{c}$ shows the distribution of the overall mass, dry mass (TS) and organic 311 dry mass (VS) of the respective initial soaked waste between the two fractions produced.

312 TS concentrations in the fractions are given in Table 3.

313 Figure 5 revealed relatively similar results for SBW, HBW and RBW samples. For these 314 samples, 86 to $92 \%$ of the initial wet mass of soaked waste was collected in ASF, and 39 315 to $52 \%$ of TS or VS were collected in PF. GBW however exhibited a distinct behavior, 
316 with more than $90 \%$ of TS or VS collected in PF. This observation suggested that the

317 biochemical composition of the waste played a strong role. In a previous article, Moretti

318 et al. (2020) reported that GBW sample was composed of lignocellulosic materials at up

319 to $82 \%$ of VS. These biopolymers are very stable, recalcitrant, and poorly soluble. They

320 were therefore collected almost quantitatively in the PF. In contrast, the other BW studied

321 here mostly contained food products, with a higher proportion of less recalcitrant, more

322 soluble compounds. Part of the TS initially present in the BW were therefore degraded

323 and leached during soaking, and therefore smaller proportions were collected in PF. 
327 Table 4 shows the results from the BMP determinations of the fractions produced from 328 the pretreatment of each BW. Figure 6 illustrates the time course of methane production 329 recorded during the BMP assays.

331 Biogas production from either fraction obtained from HBW, RBW and SBW pretreatment followed first order kinetics. No inhibition was observed. Methane productions from ASF of these $3 \mathrm{BW}$ were found in the same order of magnitude, ranging from 408 to 423

$334 \mathrm{NL}_{\mathrm{CH} 4} \cdot \mathrm{g}^{-1} \mathrm{vs}$. These results were relatively close to previously published data. Micolucci 335 et al. (2015b) obtained a production of $470 \mathrm{NL}_{\mathrm{CH} 4} \cdot \mathrm{g}^{-1} \mathrm{Vs}$ from the anaerobic digestion of pressed HBW using a mesophilic digester. Jank et al. (2015) reported slightly smaller methane potentials of $360 \mathrm{NLCH}_{4} \cdot \mathrm{g}^{-1} \mathrm{vs}$ on pressed biowaste using the BMP protocol. The differences observed may be attributed to the different origins of the waste materials and

339 the different experimental protocols used.

340 The kinetic constants determined from the curves of biogas production were also very

341 close for the 3 biowaste HBW, RBW and SBW, ranging between 0.35 and $0.40 \mathrm{~d}^{-1}$. These

342 observations suggested that the aqueous slurry fractions from these BW contained readily

343 biodegradable compounds in the forms of dissolved molecules, colloids and small 344 particles.

345 RBW and SBW samples exhibited similar methane productions from their respective PF 346 and ASF (between 408 and $455 \mathrm{NL}_{\mathrm{CH} 4} \cdot \mathrm{g}^{-1} \mathrm{vS}$ ), indicating that the soaking operation was 347 not efficient enough in extracting the readily biodegradable constituents from these BW 348 into the ASF. The corresponding kinetic constants however were smaller in PF than in 
349 ASF $\left(0.26\right.$ and $0.28 \mathrm{~d}^{-1}$ vs. 0.35 and $\left.0.40 \mathrm{~d}^{-1}\right)$, indicating that the PF fractions contained

350 more recalcitrant compounds than the corresponding ASF.

351 The efficiency of soaking operation was better with HBW, as shown by the lower BMP 352 of PF $\left(269 \pm 21 \mathrm{NL}_{\mathrm{CH} 4} \cdot \mathrm{g}^{-1} \mathrm{vs}\right)$ as compared to ASF (416 $\left.\pm 13 \mathrm{NL}_{\mathrm{CH} 4} \cdot \mathrm{g}^{-1} \mathrm{Vs}\right)$. This result 353 was attributed to the lignocellulosic contents, which was higher in HBW than in RBW 354 and SBW samples as shown in Table S1, making PF of HBW less readily biodegradable 355 than those of RBW and SBW.

356 Finally, GBW logically exhibited the smallest methane productions from each of its 357 fractions $\mathrm{ASF}$ and $\mathrm{PF}$ (160 and $60 \mathrm{NL}_{\mathrm{CH} 4} \cdot \mathrm{g}^{-1} \mathrm{vs}$, respectively) as compared to all the other 358 waste tested. The kinetic constant recorded on its PF was the smallest of all, confirming 359 the recalcitrance of its ligno-cellulosic constituents. These observations were explained 360 by the nature, origin and composition of this BW (see Table S1).

361 Figure 5d shows the proportion of the volume of methane produced by ASF and PF from 362 each BW in the BMP assays, calculated by equations 3 and 3' (see materials \& methods

363 section). It also shows the distribution of COD between each fraction of each waste, 364 calculated by eq. 4 and 4 '.

366 The distributions of COD and methane production between the two fractions followed 367 very similar patterns for each BW. The efficiency of the pretreatment operations in 368 extracting as much as possible the methane potential of the BW materials into ASF was 369 found to decrease in the following order: SBW $(67 \%)>\mathrm{HBW}(58 \%) \simeq \mathrm{RBW}(57 \%)>>$ 370 GBW (17\%). This result was fairly well correlated to the distribution of volatile solids 371 (VS, see Fig. 5c), and very correlated to the distribution of COD (Fig. 5d). Working on a 
372 mixture of HBW and GBW, do Carmo Precci Lopes et al. (2019) reported a higher

373 extraction of $82 \%$ of methane potential in aqueous slurry.

374 In our study, the pretreatment operations allowed for SBW, HBW and RBW samples to 375 concentrate in ASF between half (48\%) and more than the 2/3rds (71\%) of COD and 376 methane productivity. In contrast, with GBW sample, the same operations conducted 377 under the same conditions concentrated strongly these parameters in the PF (83-94\%).

378

\subsubsection{Composition of aqueous slurry fractions (ASF)}

Table 5 gathers the results from the chemical analyses of ASF obtained from the pretreatment of each BW. It can be seen that the aqueous slurry fractions produced from HBW, RBW and SBW exhibited very similar chemical compositions, except for N-TKN concentration which was much smaller in ASF from HBW $(177 \mathrm{mg} / \mathrm{L})$ than those from RBW and SBW (around $1000 \mathrm{mg} / \mathrm{L}$ ). This may be attributed to a higher proportion of meat products in RBW and SBW samples. The low $\mathrm{pH}$ (4.6 to 4.9) and relatively high VFA concentrations (from 3.3. to $5.1 \mathrm{~g}_{\mathrm{COD}} \cdot \mathrm{L}^{-1}$, mainly as lactic and acetic acids), suggested that some reactions of acidogenesis had already started within the biowaste during the collection time and the pretreatment of these BW, thereby confirming their high biodegradability.

391 The chemical composition of the ASF produced from GBW pretreatment was very

392 different from that of the ASF obtained from the other waste. It confirmed that GBW was 393 not adapted to anaerobic digestion. 


\subsubsection{Energy balance estimation}

398

399 The results discussed above showed the possible added-value of implementing a wet-

400 press pretreatment prior to anaerobic digestion of biowaste with low lignocellulosic

401 content $(<40 \%$ of VS).

402 Further investigations at a larger scale and complementary economic considerations appear however necessary to define the optimal conditions of implementation. Although

404 the nature and scale of the present study are actually not adapted to such estimations,

405 efforts were made to propose a simplified evaluation of the energy balance of the system.

406 Calculations are detailed in Table 6. The potential energy productions from anaerobic

407 digestion of the aqueous slurry fractions were calculated for a unit mas of organic matter

$408\left(M . \mathrm{kg}_{V S}{ }^{-1}\right)$ by multiplying the BMP values $\left(\mathrm{NL}_{\mathrm{CH} 4} \cdot \mathrm{kg}^{-1} \mathrm{vs}\right)$ by the heat of combustion of

409 methane $(35.9 \mathrm{~kJ} / \mathrm{L})$. The energy needed for the wet-press pretreatment was evaluated

410 in a simplified manner as the work developed to press the soaked waste under a constant

411 pressure of 6 bars $\left(610^{5} \mathrm{~Pa}\right)$ over a volume variation $\Delta \mathrm{V}$ equal to the difference between

412 the initial and the final volume. In addition, an overall energy yield of 0.3 was considered

413 between the electrical energy consumed and the work $-\mathrm{P} \Delta \mathrm{V}$ developed by the press. The

414 energy consumed for soaking the waste was neglected.

415 Table 6 shows that the energy consumed to run the wet-press pretreatment was very small

416 as compared to the energy potentially produced by anaerobic digestion $(>1 \%)$, with

417 exception for GBW, where the recovered amount of VS in the slurry was very small and

418 poorly degradable. In a first approach, it can therefore be considered that the

419 implementation of the pre-treatment is energetically acceptable. 


\section{Conclusions}

423 A wet mechanical pretreatment was designed to improve and facilitate methane 424 production from biowaste. The treatment consisted in separating a biodegradable aqueous 425 slurry fraction from a more recalcitrant particulate one. Pressing of soaked waste was 426 investigated and shown as a good approach according to the experimental results 427 obtained.

428 The extraction of the biodegradable organic matter into the aqueous slurry fractions ASF 429 was found better with the biowaste materials containing relatively little amounts of 430 lignocellulosic substances. The efficiency of the pretreatment operations in extracting 431 methane potential of the BW materials into ASF was found to decrease in the following 432 order: $\operatorname{SBW}(67 \%)>\mathrm{HBW}(58 \%) \simeq \mathrm{RBW}(57 \%)>\mathrm{GBW}(17 \%)$. The pretreatment 433 operations were therefore poorly efficient with respect to this criterion for waste material 434 with high lignocellulosic contents such as Green BW. Energy balance of the system was 435 highly positive considering energy production from biogas and energy demand for press436 filtration. Further investigations are in progress to scale up the results.

\section{Supplementary data}

438 E-supplementary data for this work can be found in e-version of this paper online

440 Declarations

441 Ethics approval and consent to participate

442 Not applicable 
444 Not applicable

\section{$445 \quad$ Availability of data and materials}

446 The datasets used and/or analysed during the current study are available from the

447 corresponding author on reasonable request.

$448 \quad$ Competing interests

449 The authors declare that they have no competing interests

$450 \quad$ Funding

451 French National Environmental Agency (ADEME) has funding the URBANBIOM

452 project through the GRAINE-ADEME program 2016 (grant number $n^{\circ} 1806 \mathrm{C} 0003$ ).

453

454 Authors' contributions

455 PM and MMO have conducted the experimental work, the analyses, most of data

456 interpretation and draft redaction of the article.

$457 \mathrm{RB}$ was the project coordinator, the major contributor to the design of experimental

458 work, and contributor to the redaction of the manuscript

$459 \mathrm{~PB}$ and RG were major contributors in the research project and in the redaction of the

460 manuscript.

461 JMA and $\mathrm{ABC}$ contributed in redaction of the manuscript

462 All authors have read and approved the final manuscript. 


\section{Acknowledgements}

466 The authors would like to thank the French National Environmental Agency 467 (ADEME) for funding the URBANBIOM project through the GRAINE-ADEME 468 program 2016 (grant number $\mathrm{n}^{\circ} 1806 \mathrm{C} 0003$ ).

469 This work was performed within the framework of the EUR $\mathrm{H}_{2} \mathrm{O}$ 'Lyon (ANR-17470 EURE-0018) of Université de Lyon (UdL), within the program 471 "Investissements d'Avenir" operated by the French National Research Agency (ANR). 472 473 474 


\section{References}

476 Ariunbaatar J, Panico A, Esposito G, Pirozzi F, Lens PNL (2014) Pretreatment methods 477 to enhance anaerobic digestion of organic solid waste. Applied Energ 123:143-156. 478 Baird R, Bridgewater L (2017) Standard methods for the examination of water and 479 wastewater. 23rd edition. Washington D.C. American Public Health Assoc.

480 Bernstad A (2014) Household food waste separation behavior and the importance of 481 convenience. Waste Manage 34:1317-1323.

482 Braguglia C, Gallipoli A, Gianico A, Pagliaccia P (2018) Anaerobic bioconversion of 483 food waste into energy : A critical review. Bioresour Technol 248:37-56

484 Capson-Tojo G, Rouez M, Crest M, Steyer JM, Delgenes JP, Escudié R (2016) Food 485 waste valorization via anaerobic processes: a review. Environ Sci Biotechnol 15:499547.

487

Do Carmo Precci Lopes A, Robra S, Müller W, Meirer M, Thumser F, Alessi A, Bockreis 488 A (2019) Comparison of two mechanical pre-treatment systems for impurities reduction of source-separated BW. Waste Manage 100:66-74.

490 Escamilla-Alvarado C, Poggi-Varaldo HM, Ponce-Noyola MT (2017) Bioenergy and bioproducts from municipal organic waste as alternative to landfilling: a comparative life cycle assessment with prospective application to Mexico. Environ Sci Pollut Res $24: 25602-25617$.

494 European Environment Agency (2020) Bio-waste in Europe - turning challenges into opportunities. EEA Report 04/2020. ISSN 1977-8449.

496 European Union (2008) Directive 2008/98/EC of the European Parliament and the 497 Council of 19 November 2008 on Waste and Repealing Certain Directives. Official J 498 of the European Union 22/11/2008. 
499 European Union (2018) Directive 2018/851 of the European Parliament and the Council 500 of 30 May 2018, amending Directive 2008/98/EC on waste. Official J of the European $501 \quad$ Union $14 / 06 / 2018$.

502 Fisgativa H, Tremier A, Dabert P (2016) Characterizing the variability of food waste 503 quality: A need for efficient valorisation through anaerobic digestion. Waste Manage $504 \quad 50: 264-274$.

505 Fisgativa H, Tremier A, Le Roux S, Bureau C, Dabert P (2017) Understanding the 506 anaerobic biodegradability of food waste: Relationship between the typological, 507 biochemical and microbial characteristics. J Environ Manage 188:95-107.

508 Hansen TL, Jansen JLC, Davidsson A, Christensen TH (2007) Effects of pre-treatment 509 technologies on quantity and quality of source-sorted municipal organic waste for $510 \quad$ biogas recovery. Waste Manage 27:398-405.

511 Holliger C, Alves M, Andrade D, Angelidaki I, Astals S, Baier U, Bougrier C, Buffière 512 P, Carballa M, Wilde V, Ebertseder F, Fernández B, Ficara E, Fotidis I, Frigon JC, 513 de Laclos HF, Ghasimi DSM, Hack G, Hartel M, Heerenklage J, Horvath IS, Jenicek 514 P, Koch K, Krautwald J, Lizasoain J, Liu J, Mosberger L, Nistor M, Oechsner H, 515 Oliveira JV, Paterson M, Pauss A, Pommier S, Porqueddu I, Raposo F, Ribeiro T, 516 Pfund FR, Strömberg S, Torrijos M, Eekert MV, Lier JV, Wedwitschka H, Wierinck 517 I (2016) Towards a standardization of biomethane potential tests. Water Science $518 \quad$ Technol 74:2515-2522.

519 Jank A, Müller W, Schneider I, Gerke F, Bockreis A (2015) Waste Separation Press 520 (WSP): A mechanical pretreatment option for organic waste from source separation. Waste Manage 39:71-77. 
522 Micolucci F, Gottardo M, Malamis D, Bolzonella D, Pavan P, Cecchi F (2015a) Analysis 523 of Meso/Thermo AD process applied to pressed biowaste. Waste biomass valor 6:723-731.

Micolucci F, Gottardo M, Cavinato C, Pavan P, Bolzonella D (2015b) Mesophilic and thermophilic anaerobic digestion of the liquid fraction of pressed BW for high energy yields recovery. Waste Manage 48:227-235.

Moretti P, Morais de Araujo J, Borges de Castilhos A, Buffiere P, Gourdon R, Bayard R (2020) Characterization of municipal biowaste categories for their capacity to be converted into a feedstock aqueous slurry to produce methane by anaerobic digestion. Sci Total Environ 726:137084.

NF EN 14899 (2006) Characterization of waste - Sampling of waste materials Framework for the preparation and application of a sampling plan.

Novarino D, Chiara Zanetti M (2012) Anaerobic digestion of extruded OFMSW. Bioresour Technol 104:44-50.

Pognani M, Barrena R, Font X, Sanchez A (2012) A complete mass balance of a complex combined anaerobic/aerobic municipal source-separated waste treatment plant. Waste Manage 32:799-805.

Rodríguez-Valderrama S, Escamilla-Alvarado C, Rivas-García P, Magnin JP, AlcalàRodriguez M, Garcia-Reyes RB (2020) Biorefinery concept comprising acid

Ruth BF, Montillon GH, Motonna RE (1933a) Studies in filtration: I. Critical analysis of hydrolysis, dark fermentation, and anaerobic digestion for co-processing of fruit and

545 Sidaine JM, Gass M (2013) État de l'art de la collecte séparée et de la gestion de proximité 546 des biodéchets. Awiplan ADEME. 
547 Vakalis S, Sotiropoulos K, Moustakas D, Malamis K, Vekkos M, Baratieri M (2017)

548 Thermochemical valorization and characterization of household BW. J of Environ 549 Manage 203:648-654.

550 Vesilind PA (1994) The role of water in sludge dewatering. Water Environ Res 66:4-11. 551 Weithmann N, Möller J, Löder M, Piehl S, Laforsch C, Freitag R (2018) Organic fertilizer 552 as a vehicle for the entry of microplastic into the environment. Sci Advance 553 4:eaap8060. 
554 Abbreviation List

555 ASF

Aqueous Slurry Fraction

$556 \quad \mathrm{BMP}$

Biomethane Potential

557 BW

Biowaste

558 COD

Chemical Oxygen Demand

559 GBW

Green Biowaste

560 HBW

Household Biowaste

$561 \mathrm{~L} / \mathrm{S}$

Liquid to Solid ratio

$562 \quad \mathrm{PF}$

Particulate Fraction

563 RBW

Restaurant Biowaste

564 SBW

Supermarket Biowaste

565 TS

Total Solid

566 VS

Volatile Solid

567

568 
Figures and Tables :

570

571

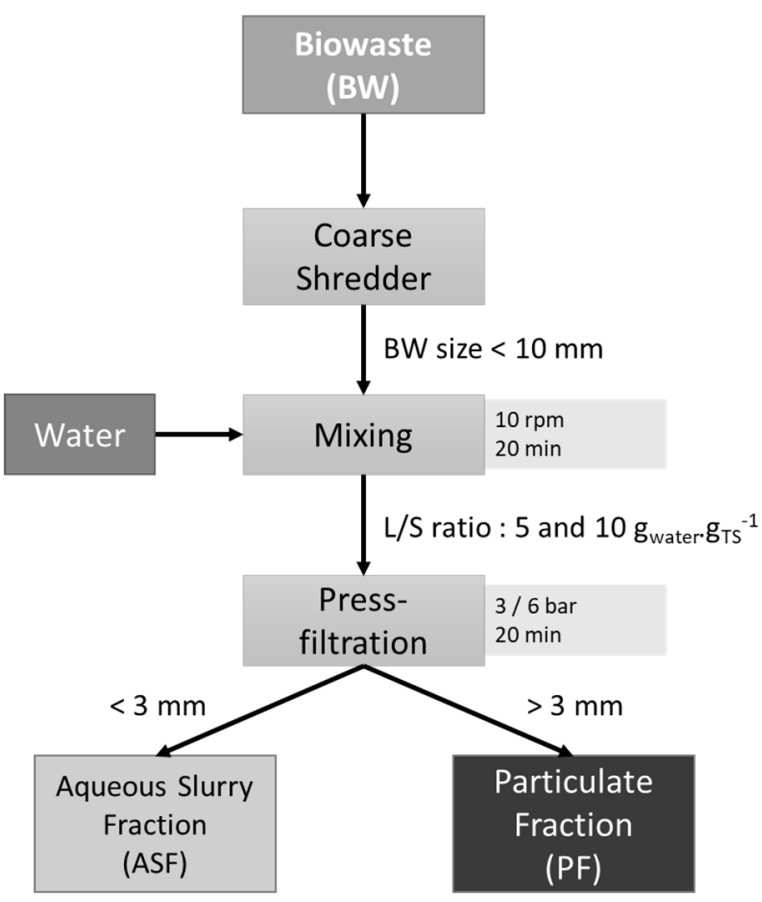

572

573 Figure 1 Flow chart of the pretreatment operations applied to each BW sample.

574 


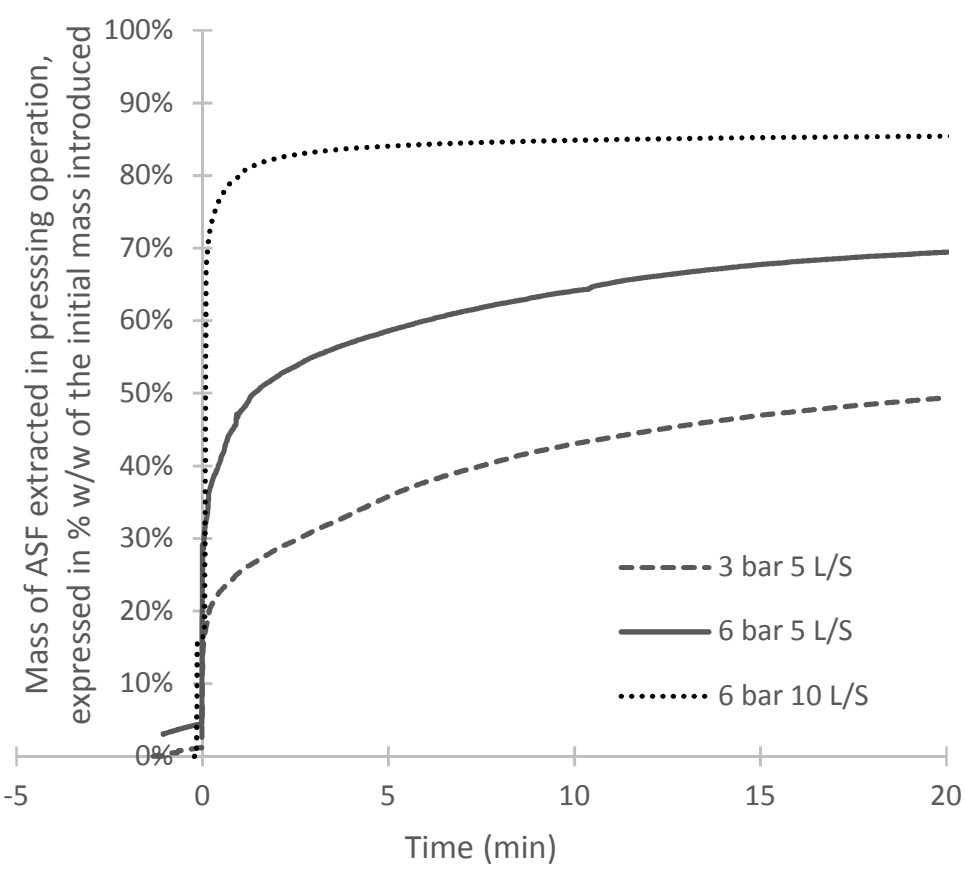

576 Figure 2 Time course of ASF extraction during the operation of pressing of soaked 577 household BW (HBW) under different operational conditions: Soaking stage at L/S of 5

$578 \mathrm{~g}_{\text {water. }} \mathrm{g}_{\mathrm{TS}}{ }^{-1}$ followed by pressing at 3 bars or 6 bars; soaking at L/S 10 followed by pressing 579 under 6 bars.

580 
581

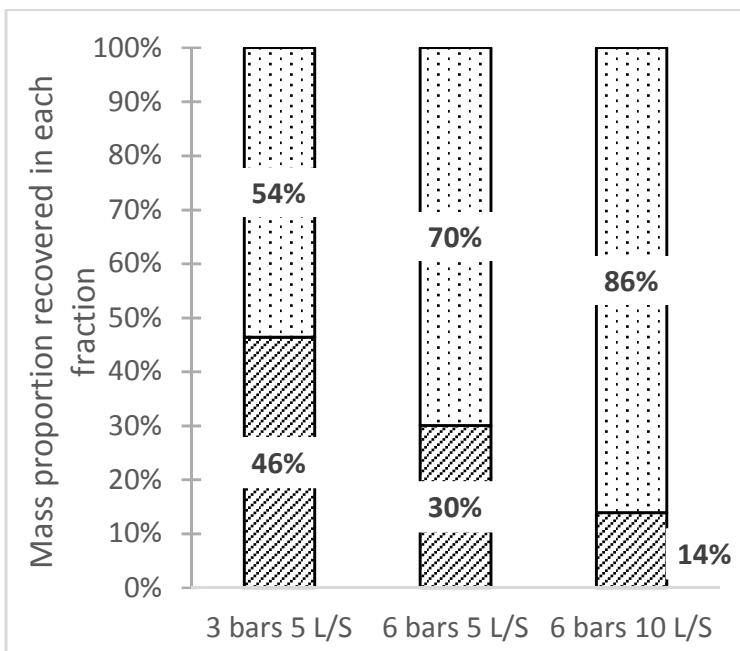

(a)

口PF ๑ASF

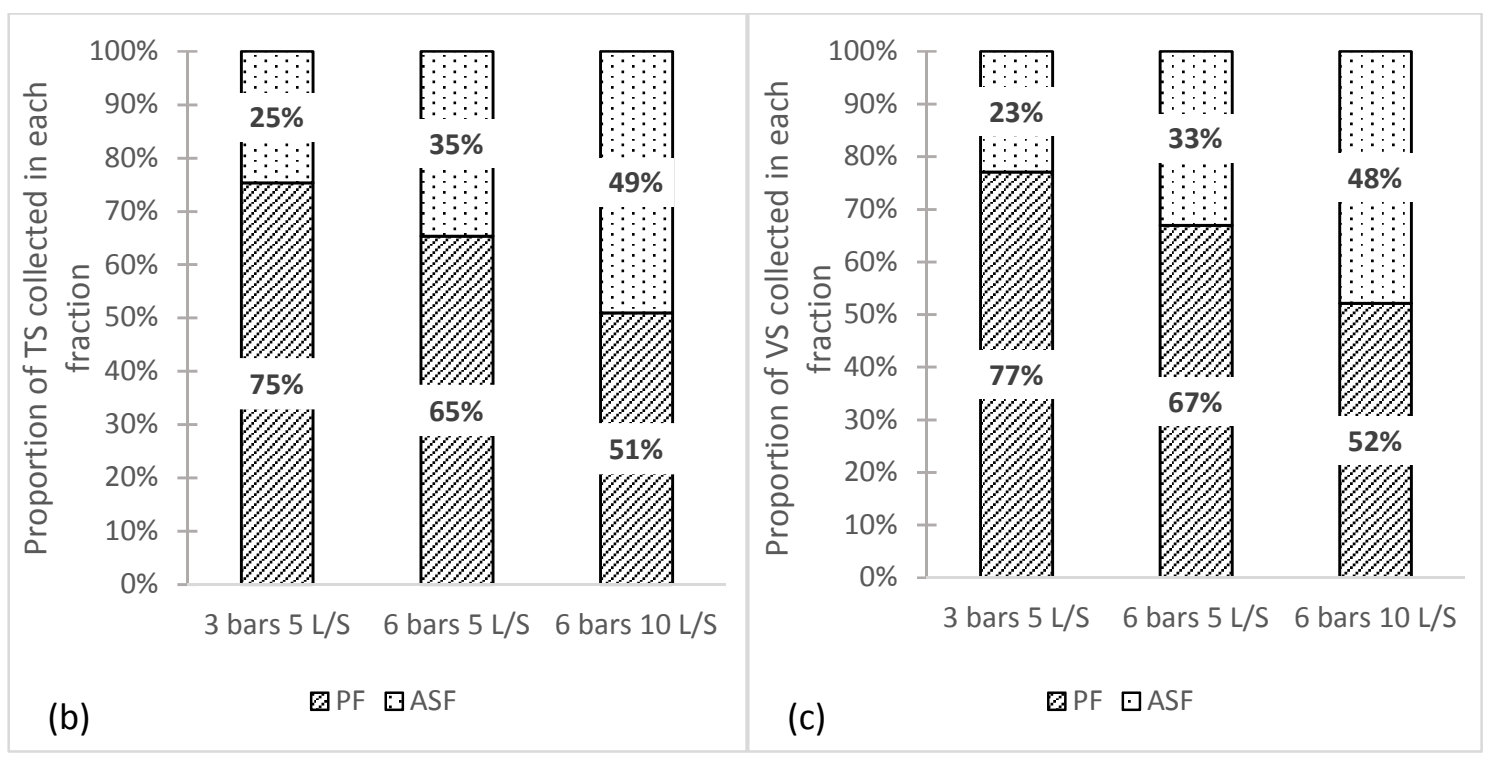

583 Figure 3 Total mass (a), total solids (b) and volatile solids (c) distributions between ASF

584 and PF for HBW pretreatment under different experimental conditions. Calculations were

585 done on the basis of $100 \mathrm{~g} \mathrm{ww} / \mathrm{TS} / \mathrm{VS}$ of household BW (HBW) before pretreatment. 


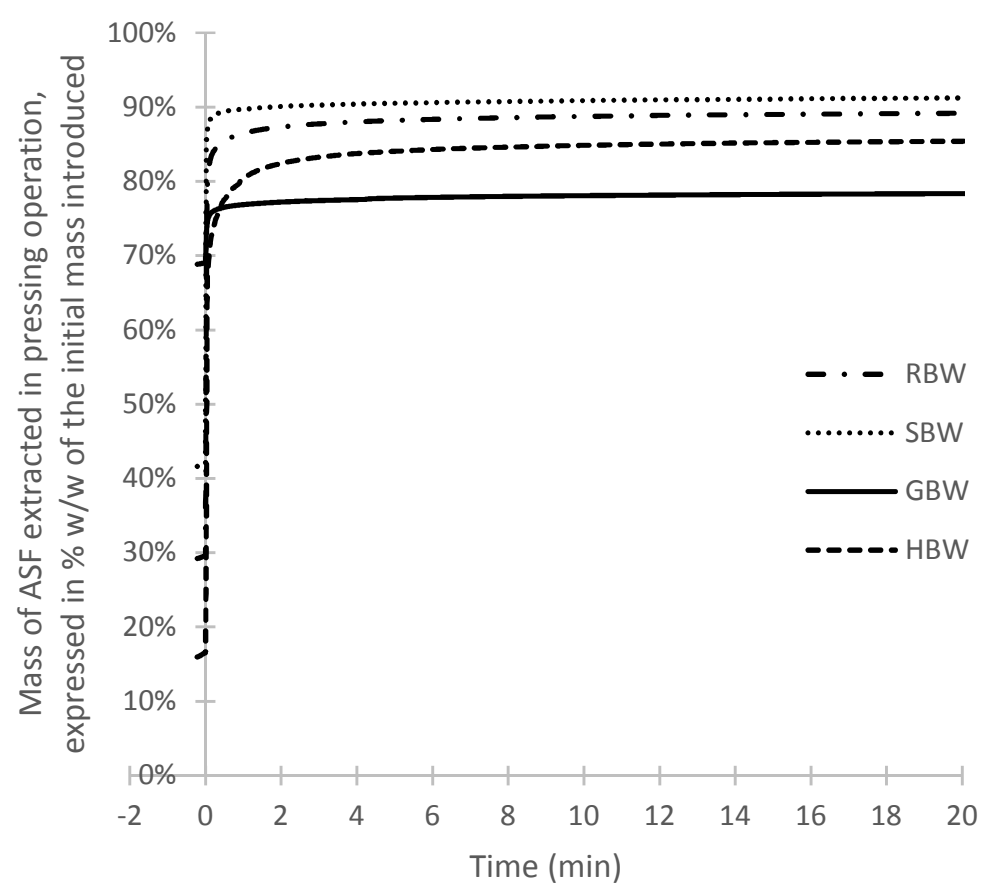

588 Figure 4 Time course of ASF extraction during the operation of pressing at 6 bars of the 589 four BW previously soaked in water for $20 \mathrm{~min}$ at $\mathrm{L} / \mathrm{S}$ ratio of $10 \mathrm{~g}_{\text {water. }} \mathrm{g}_{\mathrm{TS}}{ }^{-1}$. HBW:

590 Household BW; RBW: Restaurant BW; SBW: Supermarket BW; GBW: Green BW. 


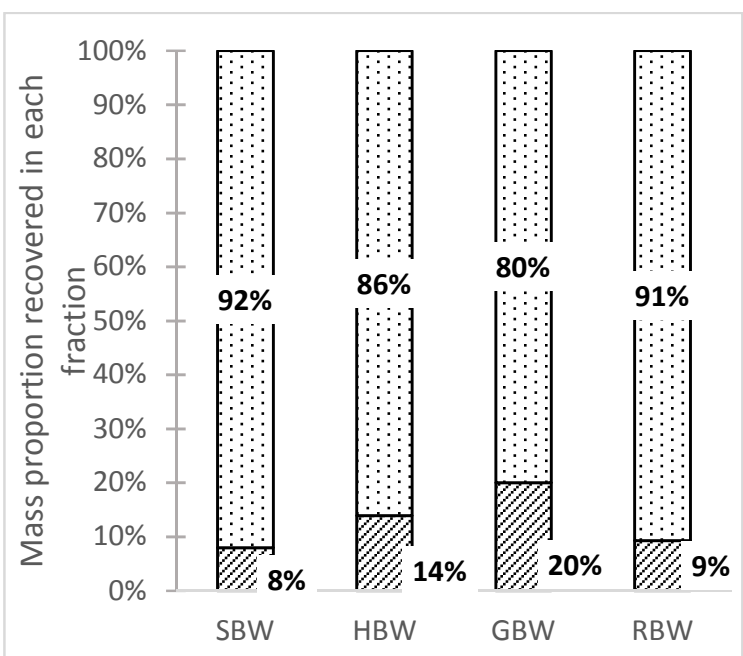

(a)

$\square P F \quad$ ASF

592

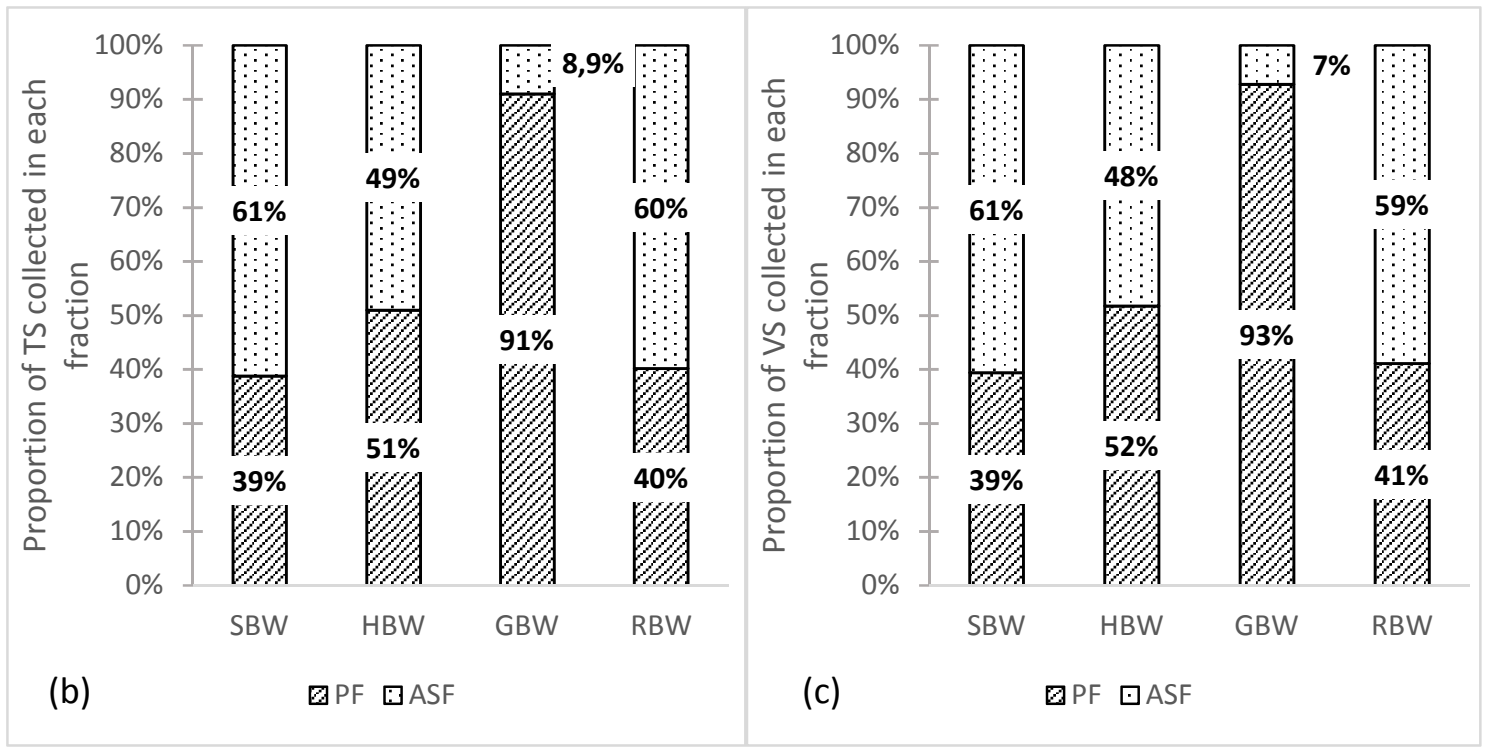

593

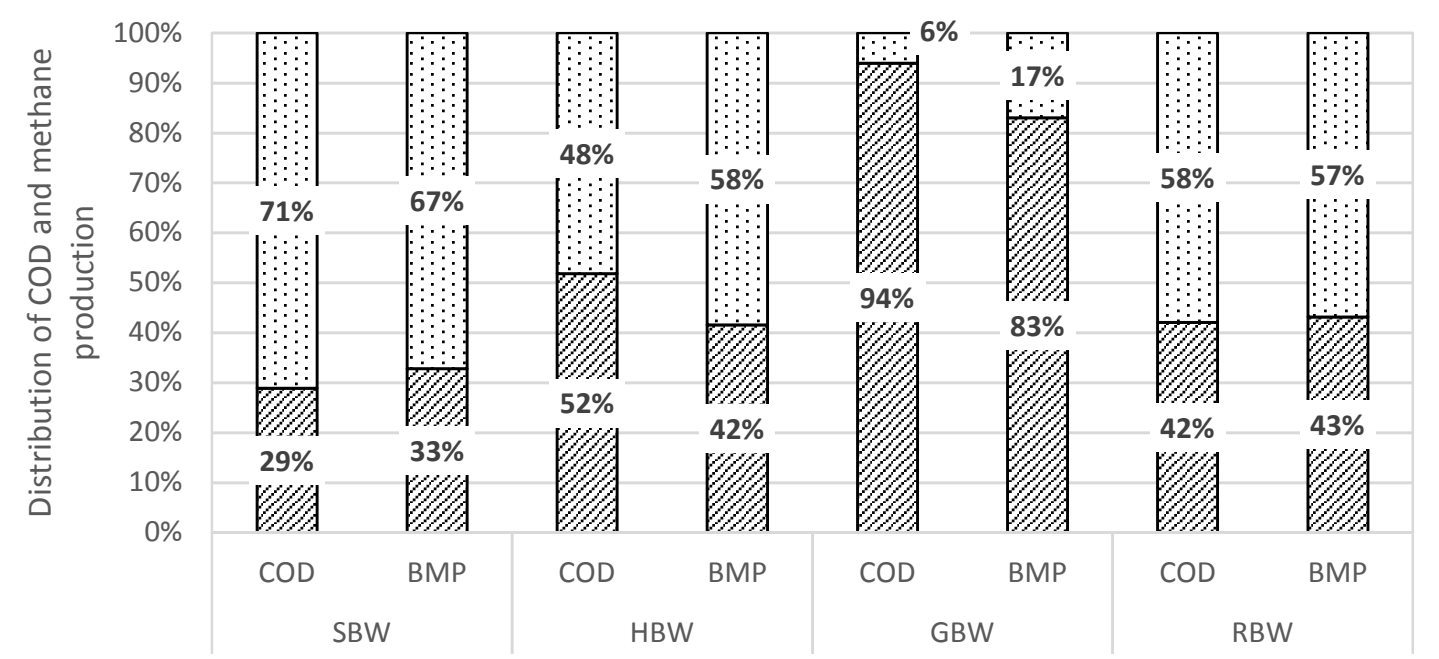

(d)

๑PF ๑ASF 
595 Figure 5 Distribution of Total mass (a), total solids (b), volatile solids (c), COD and 596 methane production (d) between ASF and PF produced from the operation of pressing at 5976 bars of the $4 \mathrm{BW}$ previously soaked in water for $20 \mathrm{~min}$ at a $\mathrm{L} / \mathrm{S}$ ratio of $10 \mathrm{~g}_{\mathrm{water}} \cdot \mathrm{g}_{\mathrm{TS}}{ }^{-1}$. 598 Supermarket BW (SBW), Household BW (HBW), Green BW (GBW) and Restaurant 599 BW (RBW).

600 
601

602

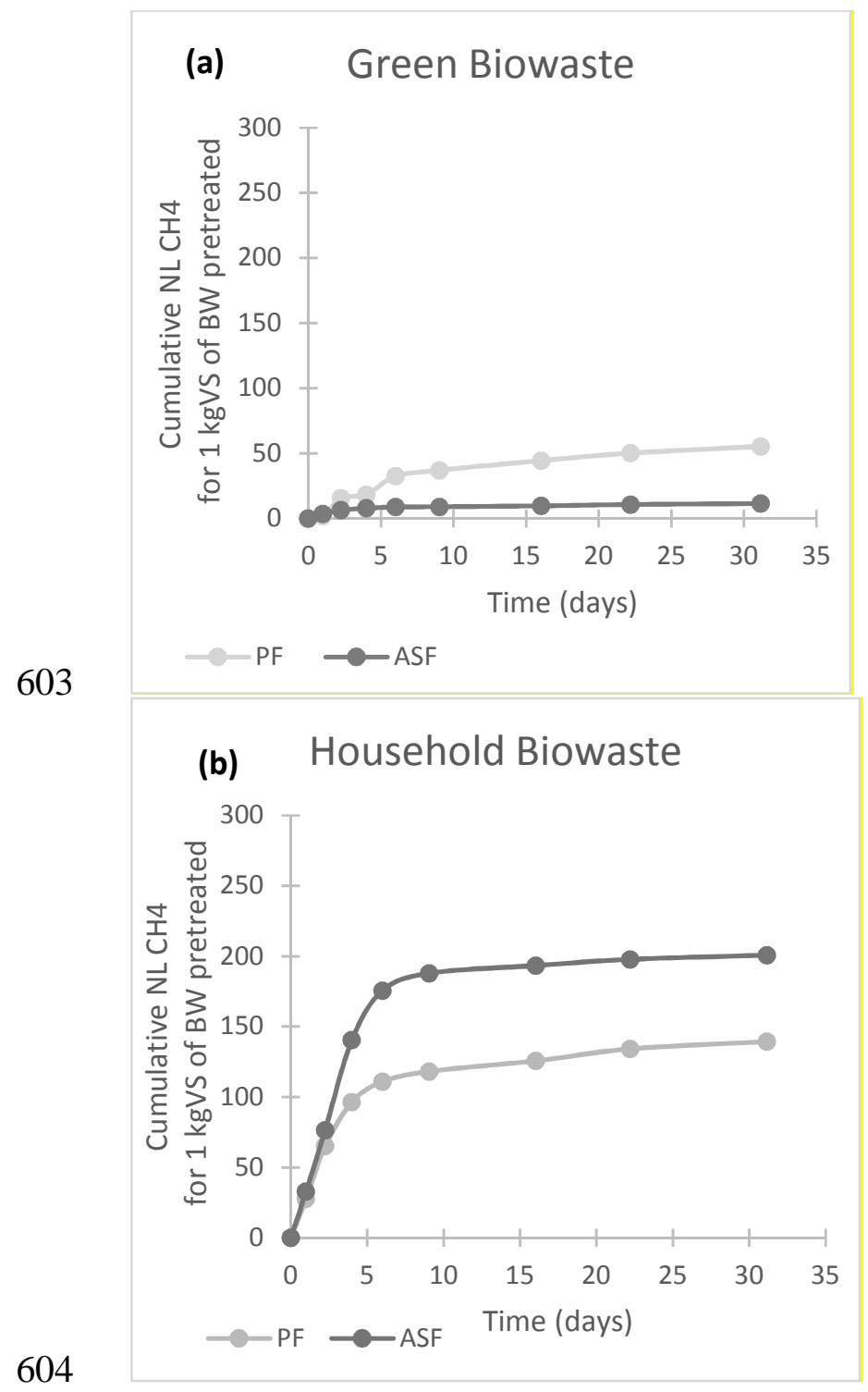




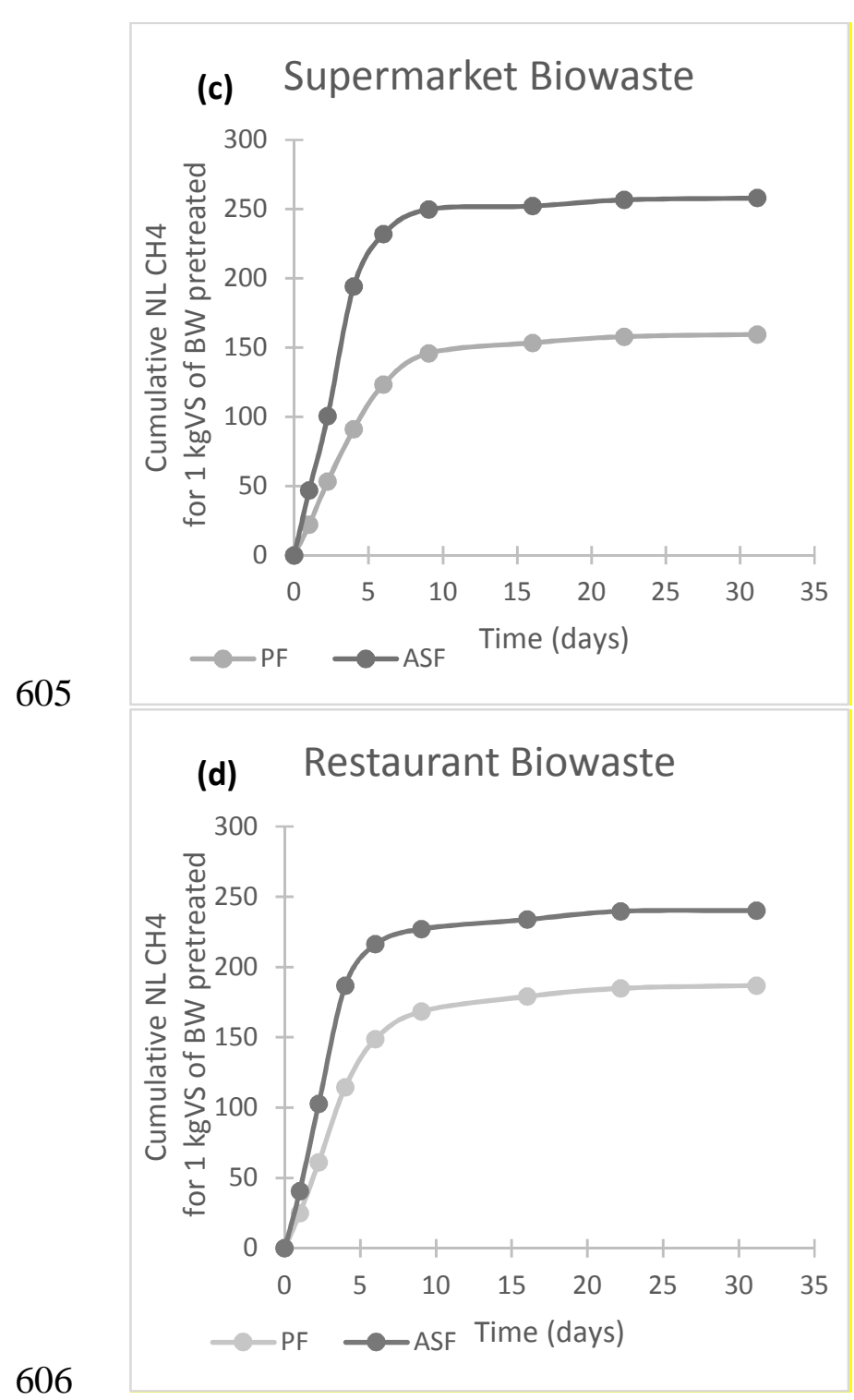

607

608 Figure 6 Production of methane of ASF and PF after pretreatment of $1 \mathrm{~kg}$ vs of GBW 609 (a), HBW (b), SBW (c), RBW (d). Results are average values of BMP triplicate tests. 610

611

612 
613 Table 1 Experimental conditions used for the pretreatment operations of the BW samples.

\begin{tabular}{lllll}
\hline Test & BW & L/S Ratio & Pressure & Pressing time \\
reference & tested & $\left(g_{\text {water }} g^{-1}\right.$ TS $)$ & $($ bar $)$ & $($ min $)$ \\
\hline 3 bar 5 L/S & HBW & 5 & 3 & 20 \\
\hline 6 bar 5 L/S & HBW & 5 & 6 & 20 \\
\hline & HBW & & & \\
& RBW & & & \\
& bar 10 L/S & 10 & 6 &
\end{tabular}

614 HBW: Household BW, RBW: Restaurant BW, SMBW: Supermarket BW, GBW: Green BW

615 
616 Table 2 TS contents of ASF and PF obtained from household BW (HBW) pretreatment

617 under different experimental conditions. Results are expressed in \% of the dry mass of

618 the respective fraction. The results are average values and standard deviation of triplicated 619 analyses.

\section{Experimental conditions}

\begin{tabular}{llll}
\hline Fraction & 3 bar 5 L/S & 6 bar 5 L/S & 6 bar 10 L/S \\
\hline Aqueous slurry (ASF) & $7.1 \pm 0.3$ & $9.3 \pm 0.6$ & $5.0 \pm 0.1$ \\
Particulate (PF) & $26.0 \pm 3.6$ & $41.0 \pm 3.5$ & $32.2 \pm 1.9$ \\
\hline
\end{tabular}

620

621 
622 Table 3 TS contents of ASF and PF after the operation of pressing at 6 bars of the four

$623 \mathrm{BW}$ previously soaked in water for $20 \mathrm{~min}$ at a $\mathrm{L} / \mathrm{S}$ ratio of $10 \mathrm{~g}_{\text {water }} \cdot \mathrm{g}^{-1} \mathrm{TS}$. Results are

624 expressed in $\%$ of the mass of the respective fraction.

\begin{tabular}{lllll}
\hline & \multicolumn{4}{c}{ Biowaste } \\
\hline Fraction & HBW & RBW & SBW & GBW \\
\hline Aqueous slurry (ASF) & $5.0 \pm 0.1$ & $6.0 \pm 0.1$ & $6.0 \pm 0.1$ & $0.9 \pm 0.1$ \\
Particulate (PF) & $32.2 \pm 1.9$ & $39.2 \pm 0.8$ & $42.8 \pm 2.0$ & $40.0 \pm 0.6$
\end{tabular}

625 Supermarket $B W(S B W)$, Household $B W(H B W)$, Green $B W(G B W)$ and Restaurant $B W(R B W)$

626

627 
629 Table 4 BMP results (methane productions and kinetic constants) of ASF and PF 630 produced from the operation of pressing at 6 bars of the four BW previously soaked in 631 water for $20 \mathrm{~min}$ at a $\mathrm{L} / \mathrm{S}$ ratio of $10 \mathrm{~g}_{\text {water. }} \mathrm{g}_{\mathrm{TS}}{ }^{-1}$. Results are average values of triplicated 632 analyses.

\section{HBW $\quad$ RBW SBW $\quad$ GBW}

\section{Aqueous slurry (ASF)}

\begin{tabular}{llllll}
\hline BMP (NLCH4. $\left.{ }^{-1} \mathrm{vs}\right)$ & $416 \pm 13$ & $408 \pm 12$ & $423 \pm 13$ & $160 \pm 10$ \\
$\mathrm{k}\left(\mathrm{d}^{-1}\right)$ & $0.35 \pm 0.07$ & $0.40 \pm 0.01$ & $0.35 \pm 0.04$ & 0.38 & \pm \\
& & & & 0.02
\end{tabular}

Particulate (PF)

\begin{tabular}{llllll}
\hline BMP $\left(\mathrm{NLCH}_{4} \cdot \mathrm{g}^{-1} \mathrm{vs}\right)$ & $269 \pm 21$ & $455 \pm 18$ & $409 \pm 28$ & $60 \pm 6$ & \\
$\mathrm{k}\left(\mathrm{d}^{-1}\right)$ & $0.32 \pm 0.01$ & $0.28 \pm 0.09$ & $0.26 \pm 0.03$ & 0.14 & \pm
\end{tabular}

0.03

633

Supermarket $B W(S B W)$, Household $B W(H B W)$, Green $B W(G B W)$ and Restaurant $B W(R B W)$

$634 *$ Calculated as the product of BMP value expressed in $\mathrm{NL}_{\mathrm{CH} 4} \cdot \mathrm{g}^{-1} \mathrm{VS}$ by the heating value of methane $35.9 \mathrm{~kJ} / \mathrm{NL}$ 
636 Table 5 Composition of the aqueous slurry fraction (ASF) produced from the operation 637 of pressing at 6 bars of the four BW previously soaked in water for $20 \mathrm{~min}$ at a L/S ratio 638 of $10 \mathrm{~g}_{\text {water. }} \mathrm{g}_{\mathrm{TS}}{ }^{-1}$. The results are average values of triplicated analyses.

\begin{tabular}{|c|c|c|c|c|c|}
\hline Parameter & Unit & HBW & RBW & SBW & GBW \\
\hline $\mathrm{pH}$ & - & $4.9 \pm 0.1$ & $4.6 \pm 0.1$ & $4.9 \pm 0.2$ & $6.3 \pm 0.1$ \\
\hline $\mathrm{N}-\mathrm{NH}_{3}$ & $m g_{N} \cdot L^{-1}$ & $69 \pm 0.2$ & $73 \pm 0.7$ & $93 \pm 1.3$ & $16 \pm 0.1$ \\
\hline N-TKN & $m g_{N} \cdot L^{-1}$ & $177 \pm 21$ & $977 \pm 27$ & $1012 \pm 13$ & $69 \pm 2$ \\
\hline COD & $g_{C O D} \cdot \mathrm{kg}_{T S}^{-1}$ & $1067 \pm 3$ & $1056 \pm 3$ & $1056 \pm 2$ & $610 \pm 1$ \\
\hline \multirow[t]{3}{*}{ VFA } & equivalent $g_{C O D} L^{-}$ & $4.5 \pm 0.6$ & $3.3 \pm 0.4$ & $5.1 \pm 0.8$ & $0.6 \pm 0.1$ \\
\hline & 1 & & & & \\
\hline & $\%$ of $C O D$ & 8.5 & 5.3 & 8.1 & 9.4 \\
\hline \multirow[t]{3}{*}{ WSC } & equivalent $g_{C O D} \cdot L^{-}$ & $10.2 \pm 1.2$ & $3.3 \pm 0.1$ & $7.5 \pm 0.8$ & $>0.1$ \\
\hline & 1 & & & & \\
\hline & $\%$ of $C O D$ & 19.3 & 5.3 & 12.0 & 0.3 \\
\hline
\end{tabular}

639 COD: Chemical Oxygen Demand; VFA: Volatile Fatty Acids; WSC: Water Soluble Carbohydrates; TKN:

640 Total Kjeldahl Nitrogen. Supermarket BW (SBW), Household BW (HBW), Green BW (GBW) and Restaurant BW $641 \quad(R B W)$

642

643 
644 Table 6 Estimations of the energy balance of the wet pressing pretreatment in the process

645 of anaerobic digestion of the 4 biowaste

HBW $\quad$ RBW $\quad$ SBW $\quad$ GBW

\section{Potential energy production from aqueous slurry}

(ASF)

\begin{tabular}{lrrrr}
\hline BMP (NL $\left.\mathrm{NH}_{4} \cdot \mathrm{kg}^{-1} \mathrm{vS}\right)$ & 416 & 408 & 423 & 160 \\
Potential energy production* $\left(\mathrm{kJ}^{\mathrm{kg}} \mathrm{kg}^{-1} \mathrm{VS}\right)$ & 14930 & 14650 & 15150 & 5740
\end{tabular}

\section{Estimated energy demand of wet pressing operation}

\begin{tabular}{lcccc}
\hline Wet pressing Pressure (in Pa) & $610^{5}$ & $610^{5}$ & $610^{5}$ & $610^{5}$ \\
Volume variation (in L) & 0.43 & 0.45 & 0.45 & 0.41 \\
Mass of sample in press (in g vs) & 9.3 & 12.3 & 12.2 & 1.20 \\
Energy yield of electrical press (dimensionless) & 0.3 & 0.3 & 0.3 & 0.3 \\
Estimated energy demand for pressing $\left(\mathrm{kJ}^{\mathrm{k}} \mathrm{kg}^{-1} \mathrm{VS}\right)$ & 93.1 & 72.4 & 73.9 & 683 \\
Estimated energy demand for pressing & & & & \\
(\% of energy produced) & 0.6 & 0.5 & 0.5 & 12 \\
\hline
\end{tabular}

